\title{
Journal of the International AIDS

\section{Effectiveness and safety of HAART regimens containing tenofovir DF + saquinavir or fosamprenavir in HIV patients: sub-analysis from PROTECTION study}

\author{
A Abdon 1 , J Cosín ${ }^{2}$, J Pasquau ${ }^{3}$, E Deig 4 , ML Álvarez ${ }^{5}, \mathrm{P} \mathrm{Ferrer}^{5}$ and \\ E Pedrol*4
}

\author{
Address: ${ }^{1}$ Hospital Son Dureta, Palma de Mallorca, Spain, ${ }^{2}$ Hospital Univ Gregorio Marañón, Madrid, Spain, ${ }^{3}$ Hospital Virgen de las nieves, \\ Granada, Spain, ${ }^{4}$ Hospital de Granollers, Barcelona, Spain and ${ }^{5}$ Medical Department Gilead Sciences, Madrid, Spain \\ * Corresponding author
}

\author{
from Ninth International Congress on Drug Therapy in HIV Infection \\ Glasgow, UK. 9-13 November 2008 \\ Published: 10 November 2008 \\ Journal of the International AIDS Society 2008, I I (SuppI I):P78 doi:I0.I I86/I758-2652-I I-SI-P78
}

This abstract is available from: http://www.jiasociety.org/content/II/SI/P78

(C) 2008 Abdon et al; licensee BioMed Central Ltd.

\section{Purpose of the study}

The concomitant use of tenofovir DF (TDF) in combination with different protease inhibitors (PIs) has been widely investigated, especially in treatment-naïve patients. Although some data exist in treatment-experienced patients receiving TDF with the commonly used PIs, such as atazanavir or lopinavir, data from other TDF+PI combinations are lacking.

\section{Methods}

The PROTECTION cohort included retrospective data from 1,428 HIV patients treated with different TDF+PI combinations from $80 \mathrm{HIV}$ clinics in Spain. We have performed a sub-analysis of those patients whose HAART regimens included at TDF in combinations including saquinavir (SQV) or fosamprenavir (FPV).

\section{Summary of results}

Tables 1 and 2 .

The most prevalent adverse event was diarrhoea in the SQV cohort (11\%) and hypertrigliceridaemia in the FPV cohort (4\%). Only four patients $(2 \%)$ withdrew their treatment due to an adverse event. One patient $(0.5 \%)$ with baseline mild renal impairment (GFR: $63 \mathrm{~mL} / \mathrm{min}$ ) withdrew his treatment due to a grade 1 GFR decrease.

\section{Conclusion}

In this cohort, concomitant use of TDF with SQV or FPV was associated with good tolerability and an adequate rate of viral effectiveness, suggesting these combinations are suitable as rescue therapy in highly treatment-experienced patients. 
Table I: Baseline characteristics.

\begin{tabular}{lll}
\hline & FPV Cohort $(\mathrm{n}=105)$ & SQV Cohort $(\mathrm{n}=98)$ \\
\hline$\%$ Male & $74 \%$ & $65 \%$ \\
Mean Age (years) & 43 & $4 \mathrm{I}$ \\
Primary HIV risk factor (\%) & IVDU (53\%) & IVDU (53\%) \\
CDC C status (\%) & $44 \%$ & $34 \%$ \\
Main reasons for TDF based regimen (\%) & Virological failure (59\%) & Virological failure (48\%) \\
& Toxicity management (19\%) & Simplification $(20 \%)$ \\
Previous time on ARV; Months. Median (IQR) & $70(2 \mathrm{I}-\mathrm{III})$ & $73(34-1 \mathrm{II})$ \\
Most common acompanying NRTls & $3 \mathrm{TC}$ or FTC (36\%) & $3 \mathrm{TC}$ or FTC (65\%) \\
& AZT or d4T (26\%) & AZT or d4T (7\%) \\
Median BL HIV RNA, c/mL (log) & ddl (II\%) & 3.3 \\
Mean BL CD4 count (cell/mm3) & 3.9 & 387
\end{tabular}

$\mathrm{BL}=$ Baseline; $\mathrm{ARV}=$ antiretrovirals. 
Table 2: Efficacy outcomes.

\begin{tabular}{lll}
\hline & FPV Cohort $(\mathrm{n}=105)$ & SQV Cohort $(\mathrm{n}=98)$ \\
\hline \% viral failure & $22 \%$ & $13 \%$ \\
Mean time of follow-up (months) & 10.5 & 9.6 \\
Mean CD4 count increase* & +84 cells $/ \mathrm{mm} 3$ & +12 cells $/ \mathrm{mm} 3$ \\
\hline
\end{tabular}

*In those subjects with 48 week data available ( $n=36$ and 26 for FPV and SQV cohorts, respectively).

Publish with Biomed Central and every scientist can read your work free of charge

"BioMed Central will be the most significant development for disseminating the results of biomedical research in our lifetime." Sir Paul Nurse, Cancer Research UK

Your research papers will be:

- available free of charge to the entire biomedical community

- peer reviewed and published immediately upon acceptance

- cited in PubMed and archived on PubMed Central

- yours - you keep the copyright 